\title{
Profitability Analysis of Rain Fed Upland Rice Production Under Smallholder Farmers in Libokemkem District, North Western Ethiopia
}

\author{
Shewaye Abera ", Abebaw Assaye \\ Ethiopian Institute of Agricultural Research, Fogera National Rice Research and Training Center, Woreta, Ethiopia \\ Email address: \\ shewit.gb2015@gmail.com (S. Abera), abebawal@gmail.com (A. Assaye) \\ ${ }^{*}$ Corresponding author \\ To cite this article: \\ Shewaye Abera, Abebaw Assaye. Profitability Analysis of Rain Fed Upland Rice Production Under Smallholder Farmers in Libokemkem \\ District, North Western Ethiopia. International Journal of Agricultural Economics. Vol. 6, No. 3, 2021, pp. 111-115. \\ doi: $10.11648 /$ j.ijae.20210603.13
}

Received: April 9, 2021; Accepted: June 7, 2021; Published: June 16, 2021

\begin{abstract}
Cultivation of rice in Ethiopia is a recent phenomenon and the crop provides advantages to rice farmers in regarding productivity basis compared to other cereal crops and contribute a lot towards ensuring food security in the country. With the advantage related to the higher productivity, the ever-increasing of domestic demand as a result of urbanization and population growth, rice production under smallholder farmers is expanding very fast. The study was designed to determine the cost of production and profitability of rice under smallholder farmers in the rain fed upland production ecosystem. Descriptive statistics and enterprise budget were used to analyze data collected from selected farmers. Descriptive analysis result reveals labor cost was the main cost item in rice production which took about $74 \%$ of the total variable cost, of which weeding cost took about $37 \%$. The enterprise budget analysis reveals sampled farmers obtained gross margin of ETB 12,084.46 per hectare from rain fed upland rice production with benefit cost ratio of 1.44 and break even price and yield of $6.45 \mathrm{ETB}$ per $\mathrm{kg}$ and 2157 kilogram per hectare, respectively and the gross margin was more sensitive for price and yield fluctuations. Thus, upland rice production is a profitable enterprise. Moreover, in order to make the enterprise more attractive, it is important to promote productivity-improving and labor-saving modern technologies and strengthen the market information delivery system and collective action by farmers.
\end{abstract}

Keywords: Upland Rice, Smallholder Farmer, Gross Margin Analysis, Sensitivity and Break even Analysis

\section{Introduction}

Rice is one of the earliest domesticated grain crops and a primary food source for nearly half the world population [1]. It is also the most rapidly growing source of food in Africa, and is of significant importance to food security and food selfsufficiency. In Ethiopia, rice cultivation is a recent phenomenon. Attempt to introduce rice were possibly initiated when the wild rice was found in the swampy and waterlogged areas of Fogera and Gambella Plains [2]. According to the report of Ministry of Agriculture and Rural Development [3] Ethiopia has 5 million hectares of highly suitable land for rainfed rice production. Despite the potential nationally, rice ranks second in productivity among major cereal crops [4] and its overall trend shows an increase in the number of rice farmers, area, production and productivity. Rice is also considered as a multiuse crop. It is a major source of income and employment not only for farmers but also many others along the value chain and it is used as food in different preparations. Its byproducts such as straw and bran are a main source of animal feed and husk is used as fuel source $[2,5]$.

Among five major rice growing ecosystems; three ecosystems are existed in Ethiopia that are rain fed upland, rain fed lowland and irrigated [6]. In upland growing ecosystem now day rice is an important crop and expanding very fast. Despite the importance, it's also competes with major factors of production with other crops. Therefore the need to analyze the profitability of rice in the upland ecosystem becomes necessary to provide information for the new entrant in to the enterprise. This research was therefore designed to estimate 
costs of production and profitability of rain fed upland rice cultivation under smallholder farmers' condition.

\section{Methodology}

\subsection{Description of the Study Area}

The study was conducted in Libo kemkem district of South Gondar Zone of Amhara Regional State, Ethiopia. The area is situated $11^{\circ} 57^{\prime} 46.6^{\prime \prime}$ to $12^{\circ} 25^{\prime} 32.6^{\prime \prime}$ north of latitude and $37^{\circ} 34^{\prime} 48.9^{\prime \prime}$ to $38^{\circ} 3^{\prime} 30.9^{\prime}$ " east of longitude. Altitude ranges from 1800-3000 meter above sea level with annual rain fall ranging from 900 to $1400 \mathrm{~mm}$ and annual temperature ranging from $18^{\circ} \mathrm{C}$ to $25^{\circ} \mathrm{C}$. Farmer depends on long rainy season for crop production and crop -livestock mixed farming system is a common practice in the area.

\subsection{Data Collection and Analysis}

Two stages random sampling technique was used. In the first stage four kebeles were selected randomly from the list of rain fed upland rice growing kebeles of Libo kemkem district. Then, given the selected kebeles households were selected randomly and the sample distribution followed probability proportional to size of households. Plot level data were collected from sample households through interview. The collected data was then analyzed using descriptive statistics such as mean, standard deviation, frequency and percentages and budgeting techniques like gross margin, sensitivity and break even analysis. Mean value was used as a measure of central tendency.

\subsection{Gross Margin Analysis}

Gross margin analysis was employed to better understand the relationship between sales revenue and cost structures [7] and used to evaluate the viability of rice production enterprise to enable better decision making

$$
\mathrm{GM}=\mathrm{TR}-\mathrm{TVC}
$$

Where GM is gross margin per hectare, TR is total revenue calculated as the product of the prevailing market price per unit output and the amount of paddy and straw produced per hectare and TVC is total variable cost that varies with the level of production and includes expenditure on inputs like seeds, fertilizer and labor etc.

\subsection{Sensitivity Analysis}

A sensitivity analysis was undertaken to assess the risk bearing ability of an enterprize under varying circumstance of price and yield and variable costs [8]. This method used to assess the effect of grain price and yield and variable costs on the gross margin of the enterprise by varying $10 \%$ above and below the received price, attained yield and incurred costs of rice farming.

\subsection{Break Even Analysis}

An enterprise, whether or not a profit maximize, often finds it useful to know what price (or output level) must be for total revenue just equal total cost. This can be done with a break even analysis. This analysis is used to determine the minimum level of output or price that allows the firm to break even [9].

$$
\text { Break- even price }=\frac{\text { Total cost }}{\text { Yield }}
$$

If unit farm-gate prices are higher than the break-even price, the farm operation makes an economic profit

$$
\text { Break }- \text { even yield }=\frac{\text { Total cost }}{\text { Sale price }}
$$

If per hectare yields are higher than the break-even yield, the farm operation makes an economic profit

\section{Result and Discussion}

\subsection{Socio-Demographic Characteristics of Respondents}

The majority of the sample households, $88 \%$ were male. Regarding the education status of the household head, $46 \%$ of the sample households were illiterate, $28 \%$ had attended at least primary school and above and $26 \%$ were capable of reading and writing (Table 1).

Table 1. Socio-Demographic Characteristics of Respondents.

\begin{tabular}{lll}
\hline Variable & Frequency & Percent \\
\hline Sex & & \\
Male & 44 & 88 \\
Female & 6 & 12 \\
Total & 50 & 100 \\
Education & & \\
Illiterate & 23 & 46 \\
Read \&write/ Religious school & 13 & 26 \\
Primary and junior secondary (1-8) & 12 & 24 \\
Secondary school (9-12) & 2 & 4 \\
Total & 50 & 100 \\
\hline
\end{tabular}

Source: own calculation

The mean age of household head was 43 years and household size of the sample households were 4.8 persons. On average the sample households own 0.93 hectare of cultivated land of which on average 0.45 hectare were allocated for rice production with the average productivity of $2713 \mathrm{~kg} / \mathrm{ha}$ it is almost similar to the national average [10]. The sample households also owned 5.3 TLU of livestock (Table 2).

Table 2. Socio-Demographic Characteristics of Respondents for Continuous variables.

\begin{tabular}{lllll}
\hline Variable & Mean & Std.dev. & Min & Max \\
\hline Age & 43 & 15.8 & 22 & 83 \\
Household Size & 4.8 & 2.13 & 1 & 10 \\
Cultivated land size & 0.93 & 0.49 & 0.25 & 3 \\
Land allocated for rice production & 0.45 & 0.21 & 0.13 & 1.3 \\
Livestock Ownership (TLU) & 5.30 & 3.37 & 0.46 & 14.45 \\
Quantity of output (kg/ha) & 2713 & 15.31 & 1400 & 4800 \\
\hline
\end{tabular}

Source: own calculation 


\subsection{Components of Cost of Rice Production}

Table 3: indicated that the per hectare total variable cost of rain fed upland rice have two components that are material cost and cost of cultural practices. The result reveals the total variable cost of rain fed upland rice was ETB 13,071.97 per hectare.

Table 3. Per hectare costs of rain fed upland rice production.

\begin{tabular}{|c|c|c|c|c|}
\hline Cost Items & Obs & Mean (ETB) & Std.dev & $\%$ share within components \\
\hline Material cost & & 3374.44 & & 26 \\
\hline Seed & 50 & 1565.38 & 517.99 & 46 \\
\hline Fertilizer & 50 & 1808.06 & 814.76 & 54 \\
\hline Cost of Cultural practices & & 9698.47 & & 74 \\
\hline Land preparation & 50 & 1656.15 & 341.47 & 17 \\
\hline Water Management & 50 & 737.38 & 726.68 & 8 \\
\hline Weeding \& fertilizer application & 50 & 3577.98 & 1804.76 & 37 \\
\hline Bird scaring \& Roughing out & 50 & 488.51 & 768.19 & 5 \\
\hline Harvesting and Pileup & 50 & 1010.47 & 477.64 & 10 \\
\hline Threshing and winnowing & 50 & 1208.84 & 322.54 & 12 \\
\hline Transporting & 50 & 478.93 & 157.47 & 5 \\
\hline Total variable cost (TVC) & & 13071.97 & & 100 \\
\hline
\end{tabular}

Source: own calculation

Cost of cultural practices was the cost component which took the maximum share in total variable cost of rice production i.e. 74\%. On average ETB 9,698.41 was incurred for cultural practices of rain fed upland rice production of which weeding cost took the lion share (37\%), followed by land preparation (17\%) threshing and winnowing (12\%) and harvesting and pileup (10\%) costs were the major cost items of cultural practices. The cultural practices of rice farming accounts three fourth of the total variable cost. This indicates rice production under smallholder farmer is labor intensive farming. The finding confirms $[11,12]$. The cost of labor took the largest portion of the total variable cost.

The material cost of rain fed upland rice production was ETB 3,374.44 which includes the cost of seed and fertilize. The contribution of material cost for the average total variable cost was $26 \%$. About $54 \%$ of the total cost of material was fertilizer cost and the rest $46 \%$ of the total material cost goes to seed expenditure (Table 3 ).
Table 4. Per Hectare Returns of Rain fed upland Rice Production.

\begin{tabular}{lllll}
\hline Item & Mean & Std. dev & Min & Max \\
\hline Paddy & $22,001.89$ & 6579.39 & 11,354 & 38,928 \\
Straw & $3,154.51$ & 1644.66 & 540 & 7,680 \\
Total return (TR) & $25,156.4$ & & 11,894 & $43,607.44$ \\
\hline
\end{tabular}

Source: own calculation

\subsection{Returns of Rice Production}

To generate returns of rice production under smallholder farmers have two components that are the paddy main component and the bi product (straw) component. The mean values of both components were considered to compute the gross returns of rice production. As indicated in Table 4 the mean value of paddy ETB 22,001.89 and the value of straw ETB 3,154.51 with gross return of ETB 25,156.4 per hectare (Table 4).

Table 5. Distribution of Revenue from Upland Rice Production.

\begin{tabular}{llll}
\hline Total revenue (ETB/ha) & Frequency & Percent & Cumulative percentage \\
\hline$<15,000$ & 3 & 6 & 6 \\
$15,000-25,000$ & 25 & 50 & 56 \\
$25,001-35,000$ & 16 & 32 & 88 \\
$>35,000$ & 6 & 12 & 100 \\
Total & 50 & 100 & \\
\hline
\end{tabular}

Source: own calculation

The sample households earned total revenue of ranging from ETB 11,894 to ETB 43,607.44. Table 5 indicates the majority of the sample households, $82 \%$ were earned an income between 15,000-35,000 ETB /ha from rice production. Similarly, about $94 \%$ of the sample farm households received revenue which was above TVC indicates the sample smallholder rice farmers made a positive gross margin.

\subsection{Profitability Analysis}

The profitability analysis result on Table 6 presents on average the sample households earned total revenue of ETB $25,156.39$ per hectare and incurred a total variable cost of ETB $13,071.93$, total fixed cost 4,420.21 and total cost of 17,492.14 per hectare. Thus, an average rice farmer earned a gross margin of ETB $12,084.46$ which is $48 \%$ of the total return. 
Table 6. Profitability Analysis.

\begin{tabular}{lll}
\hline Variables & Obs & Mean \\
\hline Total Return (TR) & 50 & $25,156.39$ \\
Total Variable cost (TVC) & 50 & $13,071.93$ \\
Total Fixed cost (TFC) & 50 & $4,420.21$ \\
Total Cost (TC) & 50 & $17,492.14$ \\
Gross Margin (TR_TVC) & 50 & $12,084.46$ \\
Profit margin (\%) & & 48 \\
Average Return Rate (ARR) & & 0.92 \\
Benefit cost Ratio & & 1.44 \\
Breakeven yield & & 2157 \\
Breakeven price & & 6.45 \\
\hline
\end{tabular}

Source: own calculation

The average rate of return reveals for each one birr invested in rice production, a farmer received 0.92 birr as a gross margin. The Benefit cost ratio 1.44 indicates that the expected benefit exceeds the expected total cost. The implication is that the total cost has to rise by $44 \%$ or a fall in benefit up to $30.47 \%$ before the ratio would be reduced to breakeven point. Thus, from the overall profitability analysis result upland rice farming is a profitable enterprise in the study area. The result is in line with [13-15]. The total revenue of rice production outweighed the total cost.

\subsection{Break Even Analysis}

Break-even analysis is used to know the minimum level of output and price that ensure the enterprise will not experience loss. The break even price was found to be ETB 6.45 per kilogram whereas break even yield was $2157 \mathrm{~kg}$. This implies that at this point of yield per hectare and price ETB per $\mathrm{kg}$ or a decline in yield up to 2157 kilogram per hectare or price drop of up to ETB 6.45 per $\mathrm{kg}$, rain fed upland rice farming would not be at loss or gain (Table 6).

Table 7. Sensitivity Analysis of Rain Fed Lowland Rice Production.

\begin{tabular}{|c|c|c|c|c|c|c|c|}
\hline \multirow[b]{2}{*}{ Item } & \multirow[b]{2}{*}{ Actual } & \multicolumn{2}{|c|}{ TVC (ETB/ha) } & \multicolumn{2}{|c|}{ Price of rice Grain } & \multicolumn{2}{|c|}{ Yield of rice grain } \\
\hline & & $\begin{array}{l}10 \% \\
\text { Increase }\end{array}$ & $\begin{array}{l}10 \% \\
\text { Reduction } \\
\end{array}$ & $\begin{array}{l}10 \% \\
\text { Increase } \\
\end{array}$ & $\begin{array}{l}10 \% \\
\text { Reduction } \\
\end{array}$ & $\begin{array}{l}10 \% \\
\text { Increase }\end{array}$ & $\begin{array}{l}10 \% \\
\text { Reduction }\end{array}$ \\
\hline Total variable cost (TVC & 13072 & $14,379.2$ & $11,764.8$ & 13,072 & 13,072 & 13,072 & 13,072 \\
\hline Rice Grain Yield & 2713 & 2713 & 2713 & 2713 & 2713 & 2984.3 & 2441.7 \\
\hline Unit price & 8.11 & 8.11 & 8.11 & 8.92 & 7.29 & 8.11 & 8.11 \\
\hline Value Grain & $22,002.43$ & $22,002.43$ & $22,002.43$ & $24,202.673$ & $19,802.18$ & $24,202.67$ & 19802.18 \\
\hline Value straw & 3155 & 3155 & 3155 & 3155 & 3155 & 3155 & 3155 \\
\hline Gross Margin (ETB) & $12,085.43$ & $10,778.23$ & $13,392.63$ & $14,285.67$ & $9,885.18$ & $14,285.67$ & $9,885.18$ \\
\hline$\%$ change in Gross Margin & & -11 & 11 & 18 & -18 & 18 & -18 \\
\hline
\end{tabular}

Source: own calculation

\subsection{Sensitivity Analysis}

Sensitivity analysis is used to assess the risk bearing ability an enterprise in relation to price, yield and total variable cost. In this case, a change of $\pm 10 \%$ in total variable cost, grain price and grain yield was considered. Table 7: indicate that rain fed upland rice production were likely to be more sensitive for both price and yield than total variable cost. A reduction or increase in total variable cost by $10 \%$ increases or decrease the gross margin by $11 \%$ while similar percent decrease or increase in price and yield of rice grain brought $18 \%$ decrease or increase in gross margin. The implication is that slight change in price and yield has a substantial effect on the profitability of upland rice production.

\section{Conclusion and Recommendation}

The Gross margin, the profit margin and benefit cost ratio obtained suggest that production of rain fed upland rice was a profitable enterprise. Though other enterprises are not incorporated in this study, the result reveals rice production in the upland ecosystem holds a promising outlook for the new entrant in the production ecosystem. Beside the profitability, upland rice production by smallholder farmers was sensitive for both fluctuations in price and yield variability. It is therefore recommended that profitability of rain fed upland rice production could be enhanced and more attractive through the use of productivity improving technologies that improve the yield and through group marketing and market information system to reduce price fluctuation. Regarding the cost, weeding cost was the major cost item which took the line share of cost of cultural practices and hence cost reducing mechanism should be in place related to labor intensive operations so as to minimize the costs of production of rice. Thus, research institution should focus on developing cost effective and environmental and gender friendly improved technologies for weeding and other cultural practices management.

\section{References}

[1] Khush G, (2001). Green revolution, the way forward. Nat Rev 2: $815-822$.

[2] Gebey T, Berhe K, Hoekstra D, Alemu B (2012). Rice value chain development in Fogera Woreda. Based on the IPMS experience, Nairobi, ILRI.

[3] Ministry of Agriculture and rural development (MoARD), (2010) National Rice Research and Development Strategy of Ethiopia.

[4] Federal Democratic Republic of Ethiopia Central Statistical Agency (2018) Agricultural Sample Survey Report on Area and Production of Major Crops Private Peasant Holdings, Meher Season, Volume I. 
[5] Addis D, Alemu D, Assaye A, Tadesse T, Tesfaye A, Thompson J, (2018). A Historical Analysis of Rice Commercialization in Ethiopia: The Case of the Fogera Plain, Agricultural Policy Research in Africa (APRA). Working Paper 18, Future Agricultures Consortium.

[6] EIAR (Ethiopian Institute of Agricultural Research). (2016). National Rice Research Pogram Strategy for the year 2016 to 2030. Unpublished document, Ethiopian Institute of Agricultural Research, Ethiopia.

[7] Kay, R. D., (1986). Farm Management, Planning, Control and Implementation. Second Edition. McGraw-Hill, inc.

[8] Robert G. H., (1984). A survey of sensitivity analysis methodology. U.S department of commerce national bureau of standards center for Applied mathematics operation Research Division. Washington, DC.

[9] Nikolaos T, Sophocles P, Michael Z, Cristopher Z., (2014). Break Even Analysis. 1st ed.bookboon.com.

[10] Federal Democratic Republic of Ethiopia Central Statistical Agency (2016) Agricultural Sample Survey Report on Area and Production of Major Crops Private Peasant Holdings, Meher Season, Volume I.

[11] Bwala M. A. and John A. U., (2018). Profitability analysis of paddy production: A case of agricultural zone 1, Niger State Nigeria. J Bangladesh Agril Univ. 16 (1): 88-92,

[12] Shewaye Abera, Adam Bekele, Abebaw Assaye, Adane Melak, (2019). International Journal of Research Studies in Agricultural Sciences. 5 (3): 30-35.

[13] Ohen S. B. and Ajah E. A., (2015). Cost and return analysis in small scale rice production in Cross River State, Nigeria. International Research Journal of Agricultural Science and Soil Science. 5 (1): 22-27.

[14] Ben-Chendo G. N, N. Lawal and Osuji M. N, (2017). Cost and Return of Paddy Rice production in Kaduna State. European Journal of Agriculture and forestry Research. 5 (3): 41-48.

[15] Uche Nkechi, Donatus, Jane and N. Uchenwachi, Margaret, (2020). Assessment of the Profitability of Rice Production in Afikpo North L. G. A. Journal of Agriculture and Ecology Research International. 21 (7): 21-29. 